\title{
ANALISIS \\ HUBUNGAN KAUSALITAS \\ ANTARA VARIABEL KUALITAS PRODUK DAN PROMOSI \\ DALAM PROSES PEMBENTUKAN KEPUTUSAN PEMBELIAN: \\ Sebuah Studi Kasus tentang Pemasaran "Air Mineral Dalam Kemasan” di Kota Bekasi
}

\author{
WACHYUDHI, $\mathbf{N}$. \\ Dosen Tetap Fakultas Ekonomi Universitas Krisnadwipayana Jakarta \\ Alamat: Kampus UNKRIS, Jatiwaringin Jakarta Timur
}

\begin{abstract}
Every company is required to be ready to face the globalization competition. In this free business competition, the requirement for a company to succeed in the competition is to achieve the goal to create and retain customers. The purpose of this research is to analyze the effect of product quality and promotion on the purchasing decision of drinking water in packaging gallon of Aqua brand to the community in Bekasi City. Population in this research is a society that take decision in buying drinking water product in packing of Aqua gallon in the Bekasi Municipality. Data analysis method used is Quantitative Analysis Method by using questionnaires data which is distributed to the 100 respondent (as the sample). The results show that product quality and promotion variables have a significant influence on purchasing decisions.
\end{abstract}

Kata Kunci: Kualitas Produk, Promosi, Keputusan Pembelian dan Air Mineral Dalam Kemasan.

\section{PENDAHULUAN}

$\begin{array}{r}\text { Fenomena hubungan kausalitas } \\ \text { prediktor }\end{array}$
antaram
mempengaruhi keputusan $\begin{array}{r}\text { konsumen } \\ \text { melakukan pembelian tampak masih relatif }\end{array}$
menarik untuk diteliti. Hal ini dikarenakan
studi terdahulu mengindikasi banyak
faktor yang menjadi pertimbangan
konsumen untuk melakukan pembelian. Di
antaranya ada yang bertumpu pada faktor
harga, kualitas produk, merek, desain, dan
promosi, serta kualitas layanan ataupun
faktor tempat. Hasil penelitian Erika Putri
Pratiwi (2010) yang mengambil judul
"Analisis Pengaruh Kualitas Produk,
Merek, dan Harga terhadap Keputusan
Pembelian Konsumen Sepeda Motor
Yamaha Jupiter Z" di Semarang
menunjukkan adanya pengaruh yang
positif dan signifikan antara kualitas
produk, merek, dan harga terhadap

keputusan pembelian konsumen. Sementara Ika Putri Iswayanti (2010), yang mengkaji tentang pengaruh kualitas produk, kualitas layanan dan harga serta tempat terhadap keputusan pembelian (Studi kasus Rumah Makan "Soto Angkring Mas Boed") di kota yang sama, juga menyimpulkan hal yang relatif tidak berbeda. Demikian kesimpulan yang serupa juga diungkap oleh Asih Purwanto (2008), yang menganalisis pengaruh kualitas produk, promosi, dan desain terhadap keputusan pembelian Sepeda Motor Yamaha Mio di wilayah Surakarta.

Dalam rangka menjajaki bagaimana strategi pemasaran yang diterapkan oleh PT Aqua Golden Mississipi (sebagai salah satu produsen Air Mineral Dalam Kemasan / AMDK yang terbesar di Indonesia), penelitian ini mencoba mengungkap variabel variabel prediktor apa saja yang diperkirakan berpotensi 
dalam mendorong keputusan konsumen melakukan pembelian. Untuk itu, sebagai model yang dipergunakan, konstruksinya hanya difokuskan pada tiga variabel yang dipandang sangat berperan. Pertama adalah kualitas produk, dan yang kedua; promosi. Kedua variabel ini diposisikan sebagai variabel prediktor, sedangkan yang ketiga: yaitu keputusan pembelian ditempatkan sebagai variabel tujuan atau variabel sasaran.

Adapun dasar pertimbangan yang melandasi kerangka desain konseptual tersebut adalah dikarenakan "kualitas produk" dipandang sebagai salah satu variabel strategis yang berkemampuan untuk mengalahkan pesaing (Kotler \& Armstrong, 2008). Dengan kata lain, hanya perusahaan dengan kualitas produk yang paling baik yang akan tumbuh dengan pesat, dan dalam jangka panjang perusahaan tersebut akan lebih berhasil dari perusahaan yang lain. Selain kualitas produk, "promosi" juga merupakan faktor penting dalam mewujudkan tujuan penjualan perusahaan. Agar konsumen bersedia menjadi pelanggan, maka mereka terlebih dahulu harus dapat mencoba atau meneliti barang-barang yang diproduksi oleh perusahaan. Di sini lah perlunya mengadakan promosi yang terarah. Hal ini dikarenakan pada gilirannya upaya ini diharapkan dapat memberikan pengaruh positif terhadap meningkatnya penjualan (Sugiyono, 2004). Artinya, melalui promosi yang tepat sasaran, perusahaan dapat lebih mengkomunikasikan produk yang dihasilkan, dan dari berbagai keunggulan produk yang dimiliki maka hal ini dapat menyebabkan konsumen merasa lebih tertarik untuk mencoba dan kemudian akan mengambil keputusan untuk membeli produk tersebut.

Atas dasar latar belakang sebagaimana yang telah dikemukakan di atas dapat kiranya diperoleh kejelasan mengenai adanya persamaan dan perbedaan antara penelitian ini dengan beberapa penelitian terdahulu.
Persamaannya adalah penelitian ini menggunakan beberapa variabel yang sama, yaitu kualitas produk, promosi dan keputusan pembelian. Sedangkan perbedaannya adalah pada variabel bebas, di mana peneliti terdahulu menggunakan variabel lain seperti merek, harga, kualitas layanan, tempat, dan desain. Sementara penelitian ini hanya menggunakan variabel kualitas produk dan promosi, sebagai variabel prediktor dalam proses pembentukan keputusan pembelian. Berikut ini adalah beberapa landasan teori yang dipergunakan untuk menjembatani kerangka analisis terhadap fenomena hubungan kausalitas antar variabel yang mempengaruhi keputusan konsumen melakukan pembelian.

\section{LANDASAN TEORI}

\subsection{Kualitas Produk}

Kualitas produk adalah kemampuan suatu produk untuk menunjukkan berbagai fungsi termasuk ketahanan, keterandalan, ketepatan dan kemudahan dalam penggunaan (lihat Kotler dan Armstrong, 2008). Lebih jauh Tjiptono (2007) menegaskan bahwa kualitas produk menggambarkan sejauh mana kemampuan produk dalam memenuhi kebutuhan konsumen. Untuk menentukan dimensi kualitas produk tersebut, antara lain dapat dilakukan melalui delapan dimensi. Pertama, kinerja (performance). Hal ini berkaitan dengan aspek fungsional suatu barang, dan merupakan karakteristik utama yang dipertimbangkan pelanggan dalam membeli barang tersebut. Kedua, fitur (features), yaitu aspek performansi yang berguna untuk menambah fungsi dasar, berkaitan dengan pilihan-pilihan produk dan pengembangannya. Ketiga, reliabilitas (reliability). Hal ini dimaksudkan sebagai suatu yang berkaitan dengan probabilitas atau kemungkinan suatu barang berhasil menjalankan fungsinya setiap kali digunakan dalam periode waktu tertentu dan dalam kondisi tertentu pula. Keempat, 
kesesuaian (conformance). Hal ini berkaitan dengan tingkat kesesuaian terhadap spesifikasi yang telah ditetapkan sebelumnya berdasarkan keinginan pelanggan. Kelima, daya tahan (durability). Yaitu suatu refleksi umur ekonomis berupa ukuran daya tahan atau masa pakai barang. Keenam, pelayanan (serviceability). Yaitu karakteristik yang berkaitan dengan kecepatan, kompetensi, kemudahan, dan akurasi dalam memberikan layanan untuk perbaikan barang. Ketujuh, estetika (aesthetics), merupakan karakteristik yang bersifat subyektif mengenai nilai-nilai estetika yang berkaitan dengan pertimbangan pribadi dan refleksi dari preferensi individual, dan yang ke delapan: kualitas yang dirasakan (perceived quality).

Definisi lain tentang kualitas produk juga dikemukakan oleh Kotler dan Armstrong yang diterjemahkan oleh Hermaya (2003) yang menyatakan bahwa "kualitas produk adalah salah satu faktor yang paling diandalkan oleh seorang pemasar dalam memasarkan suatu produk". Sedangkan menurut Gaspersz yang dikutip dari buku Jurnal Mutu Proyek Pembangunan Gedung (2004), kualitas mempunyai definisi yang berbeda dan bervariasi dari yang konvensional sampai yang lebih strategis. Definisi konvensional dari kualitas biasanya menggambarkan karakteristik langsung dari produk seperti performansi (performance), keandalan (realibility), mudah di dalam penggunaan (easy of use) dan estetika (aesthetics). Dengan demikian atas dasar uraian ini dapat disimpulkan bahwa kualitas produk adalah suatu kondisi dinamis yang saling berhubungan, meskipun dapat memiliki definisi yang berbeda tetapi produk pada intinya memiliki suatu spesifikasi terhadap suatu barang dan jasa yang dapat menimbulkan kepuasan yang memenuhi atau melebihi harapan bagi konsumen yang menggunakannya. Hal ini sejalan dengan pengertian yang dikemukakan Feigenbaum (2000), bahwa kualitas produk secara langsung dipengaruhi oleh
9 bidang dasar atau 9M, yaitu; pasar (market), (2) uang (money), (3) manajemen (management), (4) manusia (men), (5) motivasi (motivation), (6) bahan (material), (7) mesin dan mekanik (machine and mechanization), (8) metode informasi modern (modern information metode), dan (8) persyaratan proses produksi (mounting product requirement)

\subsection{Promosi}

Definisi promosi adalah salah satu unsur dalam bauran pemasaran perusahaan yang didayagunakan untuk memberitahukan, mengingatkan, dan membujuk konsumen tentang produk perusahaan (lihat Djaslim Saladin, 2003). Promosi merupakan salah satu variabel di dalam marketing mix yang sangat penting dilaksanakan oleh perusahaan dalam pemasaran produk atau jasa. Di sisi lain menurut Tjiptono (2008), promosi penjualan adalah bentuk persuasi langsung melalui penggunaan berbagai insentif yang dapat di atur untuk merangsang pembelian produk dengan segera dan meningkatkan jumlah barang yang dibeli pelanggan. Sedangkan pengertian Promosi menurut Buchari Alma (2006), promosi adalah sejenis komunikasi yang memberi penjelasan dan meyakinkan calon konsumen mengenai barang dan jasa dengan tujuan untuk memperoleh perhatian, mendidik, mengingatkan dan meyakinkan calon konsumen. Menurut Swastha dan Irawan (2002) promosi dapat diartikan sebagai suatu sistem keseluruhan dari kegiatan-kegiatan bisnis yang ditujukan untuk merencanakan, menentukan harga, mempromosikan dan mendistribusikan barang dan jasa untuk memuaskan kebutuhan baik kepada pembeli yang ada mau pun pembeli yang potensial.

Sementara Sistaningrum (2002) mengungkapkan arti promosi adalah suatu upaya atau kegiatan perusahaan dalam mempengaruhi konsumen aktual maupun konsumen potensial agar mereka mau 
melakukan pembelian terhadap produk yang ditawarkan saat ini atau di masa yang akan datang. Konsumen aktual adalah konsumen yang langsung membeli produk yang ditawarkan pada saat atau sesaat setelah promosi produk tersebut dilancarkan perusahaan. Dan konsumen potensial adalah konsumen yang berminat melakukan pembelian terhadap produk yang ditawarkan perusahaan di masa yang akan datang.

Dalam mengelola suatu sistem komunikasi pemasaran memerlukan suatu rancangan strategi dan program-program penjualan yang efektif dan efisien. Promosi penjualan merupakan unsur kunci dalam kampanye perusahaan dan promosi yang paling baik adalah promosi yang dilakukan oleh pelanggan yang puas. Dengan demikian, promosi perlu ditangani secara cermat karena masalahnya bukan hanya menyangkut pada bagaimana berkomunikasi dengan pelanggan akan tetapi juga menyangkut seberapa besar biaya yang dikeluarkan untuk biaya ini yang tentunya harus disesuaikan pada kondisi dan kemampuan perusahan.

Promosi merupakan alat komunikasi dan penyampaian pesan bersifat memberitahukan, membujuk, mengingatkan kembali kepada konsumen, para perantara atau kombinasi keduanya. Dalam promosi terdapat beberapa unsur yang mendukung jalannya sebuah promosi tersebut yang biasa disebut bauran promosi. Adapun bauran promosi menurut Philip Kotler yang tercantum dalam buku karangan Saladin (2004) dikemukakan sebagai berikut; (1) periklanan (advertising), (2) promosi penjualan (sales promotion), (3) hubungan masyarakat dan publisitas (public relation and publicity, (4) penjualan pribadi (personal selling), dan (5) pemasaran langsung (direct marketing). Dalam konteks ini, komunikasi secara langsung melalui telepon, fax, email, atau internet dipergunakan untuk mendapatkan tanggapan langsung dari konsumen secara jelas.

\subsection{Keputusan Pembelian}

Keputusan pembelian konsumen terhadap suatu produk pada dasarnya erat kaitannya dengan perilaku konsumen. Perilaku konsumen merupakan unsur penting dalam kegiatan pemasaran suatu produk yang perlu diketahui oleh perusahaan, karena perusahaan pada dasarnya tidak mengetahui mengenai apa yang ada dalam pikiran seorang konsumen pada waktu sebelum, sedang, dan setelah melakukan pembelian produk tersebut.

Adanya kecenderungan pengaruh kualitas produk, harga dan promosi terhadap keputusan pembelian yang dilakukan oleh konsumen tersebut, mengisyaratkan bahwa manajemen perusahaan perlu mempertimbangkan aspek perilaku konsumen, terutama proses pengambilan keputusan pembelian. Dalam keputusan pembelian, umumnya ada lima macam peranan yang dapat dilakukan seseorang. Kelima peran tersebut meliputi; (1) pemrakarsa (initiator), (2) pemberi pengaruh (influencer), (3) pengambil keputusan (decider), (4) pembeli (buyer), dan yang ke (5) pemakai (user) (lihat Kotler, 2000).

Pengertian keputusan pembelian pada hakekatnya merupakan suatu upaya mengidentifikasikan semua pilihan yang mungkin untuk memecahkan suatu persoalan, dan menilai pilihan-pilihan tersebut secara sistemastis dan objektif serta sasaran-sasarannya dapat menentukan keuntungan serta kerugiannya masing-masing. Definisi lain mengenai ini menurut Nugroho, (2003), adalah suatu proses pengintegrasian yang mengkombinasikan pengetahuan untuk mengevaluasi dua atau lebih perilaku alternatif, dan memilih salah satu di antaranya. Sedangkan Kotler (2002) menyatakan bahwa keputusan pembelian adalah tindakan dari konsumen untuk mau membeli atau tidak terhadap produk.

$\begin{array}{ccc}\text { Dari berbagai faktor yang } & \begin{array}{c}\text { yan } \\ \text { mempengaruhi }\end{array} \text { konsumen }\end{array}$


melakukan pembelian suatu produk atau jasa, biasanya konsumen selalu mempertimbangkan kualitas, harga dan produk yang sudah dikenal oleh masyarakat. Sebelum konsumen memutuskan untuk membeli, biasanya konsumen melalui beberapa tahap terlebih dahulu yaitu pengenalan masalah, pencarian informasi, evaluasi alternatif, keputusan membeli atau tidak, perilaku pasca pembelian. Dalam konteks ini, ada 5 faktor yang mempengaruhi keputusan pembelian terhadap suatu produk yang akan dibeli (lihat Basu Swastha dan Hani Handoko, 2000). Faktor-faktor tersebut adalah sebagai berikut;

\section{Lokasi penjual yang strategis}

Dari segi lokasi ini, pembeli akan memilih lokasi yang benar-benar strategis dan tidak membutuhkan terlalu banyak waktu, tenaga, dan biaya seperti: mudah dijangkau, dekat dengan fasilitas-fasilitas umum, atau mungkin dekat dengan jalan raya, sehingga lokasi ini dapat mendukung yang lain.

\section{Pelayanan yang baik}

Bagi konsumen yang ingin membeli suatu produk, pelayanan yang diberikan pada saat memilih sampai terjadinya transaksi pembelian sangatlah berpengaruh terhadap jadi tidaknya pembelian yang dilakukan oleh konsumen. Pelayanan yang kurang baik akan menimbulkan rasa tidak puas yang dirasakan oleh konsumen yang selanjutnya akan mempengaruhi tingkat penjualan pada waktu selanjutnya.

\section{Kemampuan tenaga penjualnya}

Dalam suatu kegiatan usaha (penjualan), tidak terlepas dari tenaga kerja baik tenaga kerja mesin maupun tenaga kerja manusia. Tenaga kerja merupakan faktor utama dalam perusahaan sehingga diperlukan sejumlah tenaga kerja yang berke mampuan dan mempunyai keterampilan tertentu yang sesuai dengan kebutuhan perusahaan untuk mendukung kegiatan dalam pemasaran.

\section{Iklan dan promosi}

Iklan dan promosi merupakan salah satu faktor penentu keberhasilan suatu program pemasaran. Sebagaimana pun berkualitasnya suatu produk, bila konsumen belum pernah mendengarnya dan tidak yakin produk itu akan berguna bagi mereka, maka mereka tidak akan membelinya.

5. Penggolongan barang

Penggolongan barang akan menjadi faktor pertimbangan oleh konsumen yang melakukan kegiatan pembelian. Penggolongan barang secara tepat dan rapi akan memudahkan konsumen di dalam melakukan pembelian.

\section{METODE PENELITIAN}

\subsection{Populasi dan Sampel Penelitian}

Populasi yang tercakup dalam penelitian ini adalah terdiri dari seluruh masyarakat yang bermukim di Kelurahan Jatirahayu Kecamatan Pondok Melati Kota Bekasi, yang mengkonsumsi Air Minum Dalam Kemasan (AMDK) merek Aqua. Sedangkan sampel yang diambil merupakan bagian dari populasi yang ingin diteliti, yang jumlahnya diperhitungkan berdasarkan perkalian antara jumlah variabel dengan masing-masing indikator yang dikali 5 sampai dengan 10, sehingga total yang diambil mencapai angka maksimal yaitu sebanyak 100 responden. Adapun teknik pengambilan sampel dilakukan berdasarkan pendekatan non probability sampling, dengan menggunakan metode accidental, di mana siapa saja yang secara kebetulan bertemu dengan peneliti dan orang tersebut dipandang cocok sebagai sumber data, maka individu yang bersangkutan dapat digunakan sebagai sampel.

\subsection{Uji Validitas}


Validitas merupakan derajat ketepatan antara data yang terjadi pada obyek pe nelitian dengan data yang dapat dilaporkan oleh peneliti. Dengan demikian data yang valid adalah data "yang tidak berbeda" antara data yang dilaporkan oleh peneliti dengan data yang sesungguhnya terjadi pada obyek penelitian (Sugiyono (2013:267), Dalam konteks ini ada dua macam validitas penelitian, yaitu validitas internal dan validitas eksternal:

a. Validitas internal berkenaan dengan derajat akurasi desain penelitian dengan hasil yang dicapai. Kalau dalam desain penelitian dirancang untuk meneliti kualitas produk, promosi dan keputusan pembelian, maka data yang diperoleh seharusnya adalah data yang akurat tentang kualitas produk, promosi dan keputusan pembelian. Data penelitian akan menjadi tidak valid, apabila yang ditemukan adalah loyalitas pelanggan.

b. Validitas eksternal berkenaan dengan derajat akurasi apakah hasil penelitian dapat digeneralisasikan atau diterapkan pada populasi di mana sampel tersebut diambil. Bila sampel penelitian representatif, instrumen penelitian valid dan reliabel, cara mengumpulkan dan analisis data benar, maka penelitian akan memiliki validitas eksternal yang tinggi.

\subsection{Uji Reliabilitas}

Untuk menguji reliabilitas pada penelitian ini digunakan teknik analisis formula Alpha Cronbach's. Menurut Priyatno (2009), suatu angket penelitian dikatakan reliable atau handal jika jawaban seseorang terhadap suatu pernyataan adalah konsisten atau stabil dari waktu ke waktu. Suatu variabel dikatakan reliable jika memiliki Cronbach alpha > 0,6 .

\subsection{Teknik Analisis Data}

Teknik analisis data yang dipergunakan untuk membuktikan pengaruh kualitas produk dan promosi pada keputusan pembelian adalah didasarkan pada metode analisis deskriptif. Selain itu, analisisnya juga diwarnai oleh analisis koefisien korelasi dan regresi berganda. Sedangkan untuk menguji asumsi klasik dipakai teknik pengujian normalitas, multikolinearitas dan uji heteroskedastisitas.

\section{HASIL PENELITIAN DAN PEMBAHASAN}

\subsection{Hasil Penelitian}

Sebelum dilakukan analisis, terlebih dahulu dilakukan pengujian data melalui uji validitas dan reliabilitas data. Berikut ini adalah hasil dari masing-masing pengujian tersebut;

\subsubsection{Uji Validitas}

Dalam upaya melakukan pengujian terhadap validitas data, studi ini menggunakan program SPSS versi 22. Perhitungan uji validitas dilakukan dengan menggunakan korelasi Bivariate Pearson (Product Moment). Kriteria pengambilan keputusan valid atau tidaknya sautu instrumen dalam penelitian ini adalah jika hasil $\mathrm{r}_{\text {hitung }}>\mathrm{r}_{\text {tabel }}$ yang diperoleh $=>$ 0.195, maka instrumen atau pernyataan dalam kuesioner dikatakan valid, sedangkan jika hasil $r_{\text {hitung }}<r_{\text {tabel }} \quad(=<$ 0.195) maka instrumen atau pernyataan dalam kuesioner dikatakan tidak valid. Hasil perhitungan uji validitas yang diperoleh dapat dilihat dalam penjelasan tabel berikut. 
TABEL 4-1 HASIL UJI VALIDITAS

\begin{tabular}{|c|c|c|c|c|}
\hline Variabel & Instrumen Data & r hitung & $r$ tabel & Ket. \\
\hline \multirow{6}{*}{ Kualitas Produk (X1) } & Instrumen 1 & 0.723 & 0.195 & Valid \\
\hline & Instrumen 2 & 0.347 & 0.195 & Valid \\
\hline & Instrumen 3 & 0.635 & 0.195 & Valid \\
\hline & Instrumen 4 & 0.657 & 0.195 & Valid \\
\hline & Instrumen 5 & 0.609 & 0.195 & Valid \\
\hline & Instrumen 6 & 0.502 & 0.195 & Valid \\
\hline \multirow{7}{*}{ Promosi (X2) } & Instrumen 1 & 0.727 & 0.195 & Valid \\
\hline & Instrumen 2 & 0.559 & 0.195 & Valid \\
\hline & Instrumen 3 & 0.719 & 0.195 & Valid \\
\hline & Instrumen 4 & 0.753 & 0.195 & Valid \\
\hline & Instrumen 5 & 0.546 & 0.195 & Valid \\
\hline & Instrumen 6 & 0.464 & 0.195 & Valid \\
\hline & Instrumen 7 & 0.459 & 0.195 & Valid \\
\hline \multirow{10}{*}{ Keputusan Pembelian (Y) } & Instrumen 1 & 0.537 & 0.195 & Valid \\
\hline & Instrumen 2 & 0.521 & 0.195 & Valid \\
\hline & Instrumen 3 & 0.525 & 0.195 & Valid \\
\hline & Instrumen 4 & 0.450 & 0.195 & Valid \\
\hline & Instrumen 5 & 0.474 & 0.195 & Valid \\
\hline & Instrumen 6 & 0.413 & 0.195 & Valid \\
\hline & Instrumen 7 & 0.436 & 0.195 & Valid \\
\hline & Instrumen 8 & 0.495 & 0.195 & Valid \\
\hline & Instrumen 9 & 0.419 & 0.195 & Valid \\
\hline & Instrumen 10 & 0.449 & 0.195 & Valid \\
\hline
\end{tabular}

Tabel 4-1, menunjukkan bahwa masing-masing item pernyataan memiliki $\mathrm{r}_{\text {hitung }}>\mathrm{r}_{\text {tabel }}(=>0.195)$ dan bernilai positif. Dengan demikian seluruh butir pernyataan tersebut dinyatakan valid.

\subsubsection{Uji Reliabilitas}

Uji reliabilitas dilakukan terhadap itemitem pernyataan yang dikatakan valid. Suatu variabel dikatakan reliabel atau handal jika jawaban terhadap pernyataan selalu konsisten. Koefisien reliabilitas instrumen dimaksudkan untuk melihat konsistensi jawaban butirbutir pernyataan yang diberikan oleh responden. Kriteria untuk pengukuran uji reliabilitas adalah jika nilai Cronbach's Alpha > 0.6, maka instrumen penelitian dikatakan reliabel, jika nilai Cronbach's Alpha $<0.6$ maka instrumen penelitian dikatakan tidak reliabel. Penghitungan dilakukan dengan program SPSS versi 22. Hasil uji reliabilitas disajikan pada tabel berikut ini.

\begin{tabular}{|c|c|c|c|}
\hline Variabel & $\begin{array}{l}\text { Refiabilitas } \\
\text { Coefficieal }\end{array}$ & $\begin{array}{c}\text { Crubbach } \\
\text { Alpha }\end{array}$ & Keterangan \\
\hline Kualeas Produk & bites pernyatsan & 0.607 & Reirabel. \\
\hline Proenusi & Titen perisyass & 0.712 & Reizal \\
\hline Keputusan Pernbelian & 10 iten pernyatsas & 0.611 & Reliabel \\
\hline
\end{tabular}

Berdasarkan hasil analisis yang tertera pada Tabel 4-2 di atas dapat diketahui bahwa masing-masing variabel memiliki nilai Cronbach Alpha yang lebih besar dari 0,60. Dengan demikian variabel kualitas produk, promosi, dan keputusan pembelian dapat dikatakan reliabel.

\subsection{Uji Hipotesis}

Untuk mengetahui signifikansi pengaruh variable-variabel bebas secara bersama-sama atas suatu variabel terikat digunakan uji F. Hasil pengujian hipotesis secara simultan dengan menggunakan program SPSS versi 22 adalah sebagai berikut:

\begin{tabular}{|c|c|c|c|c|c|c|}
\hline \multicolumn{7}{|c|}{ Tabel 4-3. Hasil Ketepatan Model (Uji F) } \\
\hline Mode & & Sum of Squares & df & Mean Square & $\mathrm{F}$ & Sig. \\
\hline \multirow[t]{3}{*}{ 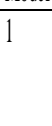 } & Regression & 1055.901 & 2 & 527.951 & 57.615 & $.000^{\circ}$ \\
\hline & Residual & 888.849 & 97 & 9.163 & & \\
\hline & Total & 1944.750 & 99 & & & \\
\hline
\end{tabular}

Berdasarkan output SPSS pada Tabel 4-3 dapat diketahui bahwa nilai regresi memiliki tingkat signifikansi 0,000. Nilai ini $<0,05$. Adapun nilai $F_{\text {hitung }}$ sebesar 57,615., dan nilai $F_{\text {tabel }}$ pada tingkat signifikan sebesar 5\%, dengan perhitungan degree of freedom $(\mathrm{df} 1)=\mathrm{k}-$ $1=3-1=2$ dan untuk derajat bebas penyebut $(\mathrm{df} 2)=\mathrm{n}-\mathrm{k}=100-3=97$ adalah sebesar 3,09. Jika kedua nilai ini dibandingkan maka nilai $\mathrm{F}_{\text {hitung }}>$ dari $\mathrm{F}_{\text {tabel }}$ ( $57,615>3,09)$. Dengan hasil perbandingan tersebut, maka Ho ditolak dan Ha diterima. Sehingga hipotesis yang menyatakan "ada pengaruh yang positif dan signifikan antara kualitas produk dan promosi terhadap keputusan pembelian Air Minum Dalam Kemasan (AMDK) pada masyarakat di Kelurahan Jatirahayu Kecamatan Pondok Melati Kota Bekasi" dapat diterima.

Uji t (parsial) dilakukan untuk menggambarkan seberapa jauh pengaruh 
variabel kualitas produk dan promosi secara individual atau sendiri-sendiri terhadap variabel keputusan pembelian. Hasil pengujian hipotesis secara parsial dengan menggunakan program SPSS adalah sebagai berikut:

\section{Tabel 4-4. Koefisien determinasi antara kualitas produk Terhadap Keputusan Pembelian}

\begin{tabular}{|c|c|c|c|c|}
\hline Model & $\mathrm{R}$ & $\begin{array}{l}\mathrm{R} \\
\text { Square }\end{array}$ & $\begin{array}{l}\text { Adjusted } \\
\text { R Square }\end{array}$ & $\begin{array}{l}\text { Std. Error } \\
\text { of the } \\
\text { Estimate }\end{array}$ \\
\hline 1 & $.685^{\mathrm{a}}$ & .469 & .463 & 3.247 \\
\hline
\end{tabular}

Berdasarkan Tabel 4-4, perhitungan atas korelasi didapat $\mathrm{R}=0,685$ hal ini menunjukkan bahwa hubungan antara variabel Kualitas Produk terhadap Keputusan Pembelian adalah positif dan kuat. Artinya jika Kualitas Produk meningkat maka Keputusan Pembelian juga akan meningkat. Dari tabel di atas dapat dilihat hasil penelitian koefisien determinasi diperoleh nilai R Square sebesar 0,469. Artinya sebesar 46,9\% variabel Kualitas Produk ( $\left.\mathrm{X}_{1}\right)$ mempengaruhi variabel Keputusan Pembelian (Y), dan sisanya sebesar $53,1 \%$ dipengaruhi oleh variabel-variabel lain. Selanjutnya untuk mengetahui apakah pengaruh Kualitas Produk terhadap Keputusan Pembelian secara parsial, dapat dilihat pada tabel uji t sebagai berikut:

Tabel 4-5. Tabel uji ( parsial) kualitas produk Terhadap keputusan pembelian

\begin{tabular}{|c|c|c|c|c|c|}
\hline \multirow[b]{2}{*}{ Model } & & \multicolumn{2}{|c|}{ Unstandardized Coefficients } & \multirow[b]{2}{*}{ t } & \multirow[b]{2}{*}{ Sig. } \\
\hline & & B & Std. Error & & \\
\hline 1 & (Constant) & 11.418 & 2.147 & 5.317 & .000 \\
\hline & Kualitas__Produk & .978 & .105 & 9.295 & .000 \\
\hline
\end{tabular}

Sumber : Data Primer, diolah tahum 2016

Berdasarkan hasil analisis statistik pada Tabel 45, hasil regresi linear sederhana pada pengaruh kualitas produk terhadap keputusan pembelian, adalah dengan persamaan sebagai berikut: $\mathbf{Y}=$ $\mathbf{1 1 , 4 1 8}+\mathbf{0 , 9 7 8 X _ { 1 }}$
Nilai Konstanta (a) sebesar 11,418 menunjukkan jika variabel Kualitas Produk $\left(\mathrm{X}_{1}\right)$ bernilai nol atau tidak ada variabel independent yang mempengaruhi variable Keputusan Pembelian (Y), maka nilai Keputusan Pembelian (Y) sebesar 11,418. Nilai Koefisien Kualitas Produk $\left(\mathrm{X}_{1}\right)$ adalah sebesar 0,978. Nilai Kualitas Produk $\left(\mathrm{X}_{1}\right)$ yang positif menunjukkan adanya hubungan yang searah antara variabel Kualitas Produk dengan Keputusan Pembelian Air Minum Dalam Kemasan (AMDK) merek Aqua. Hal ini berarti setiap terjadi kenaikan Kualitas Produk sebesar 1 maka akan meningkatkan Keputusan Pembelian sebesar 0,978 (dengan asumsi nilai koefisien variabel lain tetap atau konstan).

Nilai $t_{\text {hitung variabel Kualitas Produk }}$ $\left(\mathrm{X}_{1}\right)$ adalah sebesar 9.295 dengan tingkat signifikan 0,000. Dengan menggunakan taraf signifikan sebesar 5\%, dan dari tabel distribusi nilai $t_{\text {tabel }}$ didapat dari perhitungan degree of freedom $(\mathrm{df1})=\alpha=$ 0.05 dan untuk derajat bebas penyebut $($ df 2$)=\mathrm{n}-\mathrm{k}=100-2=98(0.05 ; 98)$ yaitu nilai $\mathrm{t}_{\text {tabel }}$ sebesar 1.98447 .

Berdasarkan kriteria uji hipotesis yaitu $t_{\text {hitung }}>t_{\text {tabel }}(9.295>1.98447)$ maka dapat dinyatakan bahwa Ho ditolak dan $\mathrm{Ha}$ diterima. Artinya bahwa variabel Kualitas Produk $\left(\mathrm{X}_{1}\right)$ berpengaruh signifikan terhadap Keputusan Pembelian Air Minum Dalam Kemasan (AMDK) merek Aqua.

Tabel 46. Koefisien determinasi antara promosi terhadap keputusan pembelian

\begin{tabular}{|c|c|c|c|c|}
\hline \multirow[b]{2}{*}{ Yodel } & \multicolumn{3}{|r|}{ Adjusted R } & \\
\hline & $R$ & RSpquare & Square & Std Error of the Estimate \\
\hline i & $.46^{3}$ & 173 & .165 & 4180 \\
\hline
\end{tabular}

Berdasarkan Tabel 4-6, perhitungan atas korelasi didapat $\mathrm{R}=0,416$ hal ini menunjukkan bahwa hubungan antara variabel promosi terhadap keputusan pembelian adalah positif dan cukup kuat. Artinya jika promosi meningkat, maka keputusan pembelian juga akan meningkat. 
Dari tabel diatas dapat dilihat hasil penelitian koefisien determinasi diperoleh nilai R Square sebesar 0,173. Fenomena ini mengindikasi bahwa sebesar $17,3 \%$ variabel promosi $\left(\mathrm{X}_{2}\right)$ mempengaruhi variabel keputusan pembelian (Y), dan sisanya sebesar $82,7 \%$ dipengaruhi oleh variabelvariabel lain. Selanjutnya untuk mengetahui secara parsial tentang pengaruh promosi terhadap keputusan pembelian, hal ini dapat dilihat dari hasil pengujian sebagaimana tertera pada tabel uji t berikut ini;

\begin{tabular}{|c|c|c|c|c|c|c|}
\hline \multirow[b]{2}{*}{ Model } & & \multicolumn{2}{|c|}{ Lnstandardized Coefficients } & \multirow{2}{*}{$\begin{array}{c}\begin{array}{c}\text { Standardized } \\
\text { Coefficients }\end{array} \\
\text { Beta }\end{array}$} & \multirow[b]{2}{*}{$t$} & \multirow[b]{2}{*}{ Sig. } \\
\hline & & B & Std. Error & & & \\
\hline$i$ & (Constant) & 21.091 & 2.256 & & 9.348 & .000 \\
\hline & Promosi & 456 & .101 & 416 & 4.532 & .000 \\
\hline
\end{tabular}

Sumber : Nota Promer. doloh rahum 2016

Pada Tabel 4-7, hasil regresi linear sederhana pada pengaruh promosi terhadap keputusan pembelian, adalah dengan persamaan sebagai berikut : $\mathbf{Y}=$ $21,091+0,456 X_{2}$

Nilai konstanta (a) sebesar 21,091 menunjukkan jika variabel Promosi $\left(\mathrm{X}_{2}\right)$ bernilai nol atau tidak ada variabel independent yang mempengaruhi variabel keputusan pembelian (Y), maka nilai keputusan pembelian (Y) sebesar 21,091. Nilai koefisien promosi $\left(\mathrm{X}_{2}\right)$ adalah sebesar 0,456 . Nilai promosi $\left(\mathrm{X}_{2}\right)$ yang positif menunjukkan adanya hubungan yang searah antara variabel Promosi dengan Keputusan Pembelian Air Minum Dalam Kemasan (AMDK) merek Aqua. Hal ini berarti setiap terjadi kenaikan Promosi sebesar 1 maka akan meningkatkan Keputusan Pembelian sebesar 0,456 (dengan asumsi nilai koefisien variabel lain tetap atau konstan). Nilai $t_{\text {hitung }}$ variabel Promosi $\left(\mathrm{X}_{2}\right)$ adalah sebesar 4.532 dengan tingkat signifikan 0,000. Dengan menggunakan taraf signifikan sebesar 5\%, dan dari tabel distribusi nilai $t_{\text {tabel }}$ didapat dari perhitungan degree of freedom $(\mathrm{df1})=\alpha=$ 0.05 dan untuk derajat bebas penyebut $(\mathrm{df} 2)=\mathrm{n}-\mathrm{k}=100-2=98(0.05 ; 98)$ yaitu nilai $t_{\text {tabel }}$ sebesar 1.98447 . Berdasarkan kriteria uji hipotesis yaitu $t_{\text {hitung }}>t_{\text {tabel }}(4.532>1.98447)$ maka dapat dinyatakan bahwa Ho ditolak dan $\mathrm{Ha}$ diterima. Artinya bahwa variabel Promosi $\left(\mathrm{X}_{2}\right)$ berpengaruh signifikan terhadap Keputusan Pembelian Air Minum Dalam Kemasan (AMDK) merek Aqua

\section{PEMBAHASAN.}

\subsection{Pengaruh Secara Simultan Antara Variabel Kualitas Produk dan Promosi Terhadap Keputusan Pembelian}

Dari penyebaran kuesioner ke 100 responden masyarakat yang mengkonsumsi Air Minum Dalam Kemasan (AMDK) merek Aqua di Kelurahan Jatirahayu Kecamatan Pondok Melati Kota Bekasi, diperoleh data yang dapat diolah dengan menggunakan program SPSS versi 22. Dari hasil pengolahan data tersebut nilai $\mathrm{R}$ Square didapat sebesar 0.543, yang artinya sebesar $54,3 \%$ variabel independent Kualitas Produk $\left(\mathrm{X}_{1}\right)$ dan Promosi $\left(\mathrm{X}_{2}\right)$ mempengaruhi variabel dependent Keputusan Pembelian (Y) dan sisanya sebesar $45,7 \%$ dipengaruhi oleh variabelvariabel lain seperti harga, kualitas pelayanan, citra merek, harga dan lainlain. Dari uji $\mathrm{F}$ diperoleh hasil $\mathrm{F}_{\text {hitung }}>$ dari $\mathrm{F}_{\text {tabel }}$ $(57,615>3,09)$ dan signifikan sebesar 0,000 yang jauh lebih kecil dari tingkat signifikansi 0,05 , dapat dinyatakan bahwa Ho ditolak dan Ha diterima. Maka secara umum dapat disimpulkan bahwa ada pengaruh secara simultan antara Kualitas Produk dan Promosi terhadap Keputusan Pembelian Air Minum Dalam Kemasan (AMDK) merek Aqua pada masyarakat di Kota Bekasi.

\subsection{Pengaruh Secara Parsial Antara Variabel Kualitas Produk Terhadap Keputusan Pembelian}


Dari penelitian ini nilai $\mathrm{R}$ square didapat sebesar 0.469 , yang artinya sebesar $46,9 \%$ variabel independent Kualitas Produk $\left(\mathrm{X}_{1}\right)$ mempengaruhi variabel dependent Keputusan Pembelian (Y) dan sisanya sebesar $53,1 \%$ dipengaruhi oleh variabel-variabel lain seperti harga, kualitas pelayanan, citra merek dan lainlain. Dari uji $\mathrm{t}$ diperoleh hasil $\mathrm{t}_{\text {hitung }}>$ $\mathrm{t}_{\text {tabel }}(9.295>1.98447)$ dan nilai signifikan sebesar 0,000 yang jauh lebih kecil dari tingkat signifikan 0,05 , dapat dinyatakan bahwa Ho ditolak dan $\mathrm{Ha}$ diterima. Sehingga secara umum dapat disimpulkan bahwa ada pengaruh secara parsial antara Kualitas Produk terhadap Keputusan Pembelian Air Minum Dalam Kemasan (AMDK) merek Aqua.

\subsection{Pengaruh Secara Parsial Antara Variabel Promosi Terhadap Keputusan Pembelian.}

Dari penelitian ini nilai $\mathrm{R}$ Square didapat sebesar 0,173 , yang artinya sebesar $17,3 \%$ variabel independent Promosi $\left(\mathrm{X}_{2}\right)$ mempengaruhi variabel dependent Keputusan Pembelian (Y) dan sisanya sebesar $82,7 \%$ dipengaruhi oleh variabelvariabel lain seperti harga, kualitas pelayanan, citra merek dan lainlain. Dari uji $\mathrm{t}$ diperoleh hasil $\mathrm{t}_{\text {hitung }}>\mathrm{t}_{\text {tabel }}(4.532>$ 1.98447) dan nilai signifikan sebesar 0,000 yang jauh lebih kecil dari tingkat signifikan 0,05 , dapat dinyatakan bahwa Ho ditolak dan Ha diterima. Maka secara umum disimpulkan bahwa ada pengaruh secara parsial antara Promosi terhadap Keputusan Pembelian Air Minum Dalam Kemasan (AMDK) merek Aqua pada masyarakat di Kelurahan Jatirahayu Kecamatan Pondok Melati Kota Bekasi.

\section{KESIMPULAN DAN IMPLIKASI}

\subsection{Kesimpulan}

Berdasarkan hasil analisis dan pembahasan yang dilakukan, maka dapat ditarik beberapa kesimpulan berikut ini;
1. Kualitas Produk dan Promosi berpengaruh positif terhadap Keputusan Pembelian Air Minum Dalam Kemasan (AMDK) Merek Aqua di Kelurahan Jatirahayu Kelurahan Pondok Melati Kota Bekasi, hal ini dibuktikan dengan nilai $\mathrm{F}_{\text {hitung }}>$ dari $F_{\text {tabel }}(57,615>3,09)$ dan signifikan sebesar 0,000 yang jauh lebih kecil dari tingkat signifikansi 0,05. Kualitas Produk berpengaruh positif terhadap Keputusan Pembelian Air Minum Dalam Kemasan (AMDK), hal ini dibuktikan dengan nilai $t_{\text {hitung }}>$ $t_{\text {tabel }}(9.295>1.98447)$ dan nilai signifikan sebesar $0,000<$ tingkat signifikan 0,05.

2. Promosi berpengaruh positif pula terhadap Keputusan Pembelian Air Minum Dalam Kemasan (AMDK), hal ini dibuktikan dengan nilai $t_{\text {hitung }}>t_{\text {tabel }}$ $(4.532>1.98447)$ dan nilai signifikan sebesar $0,000<$ dari tingkat signifikan 0,05 .

\subsection{Implikasi}

Berdasarkan hasil penelitian, pembahasan, dan kesimpulan, maka sebagai implikasi yang dapat dkemukakan antara lain adalah sebagai berikut;

* Hendaknya pihak produsen senantiasa mempertahankan mutu atau kualitas produk yang dihasilkan, dan selalu memperhatikan sumber mata air yang akan diolah secara higienis,

* Terus meningkatkan kegiatan promosi. baik melalui media cetak atau pun elektronik. Terlebih melalui media iklan dengan selalu memperhatikan desain yang menarik dan inovatif, seperti yang telah dilakukan selama ini.

* Kegiatan menjadi sponsor pada event event berskala nasional ataupun internasional, dapat pula terus dilakukan sesuai budget yang dianggarkan.

* Penelitian lanjut dapat pula terus dilakukan dan dikembangkan, guna 
mengkaji lebih jauh faktor faktor lain yang diperkirakan dapat mempengaruhi keputusan pembelian, misalnya faktor budaya, sosial, atau psikologis konsumen.

\section{DAFTAR PUSTAKA}

Akdon, dan Ridwan. 2006. Aplikasi Statistika Dan Metode Penelitian Untuk Administrasi Dan Manajemen. Bandung : Dewa Ruci.

Alma, Buchari. 2006. Manajemen Pemasaran dan Pemasaran Jasa. Bandung: CV Alfabeta.

Assauri, Sofyan. 2004. Manajemen Produksi dan Operasi. Jakarta: Lembaga Fakultas Ekonomi UI.

Ferdinand. 2006. Metode Penelitian Manajemen: Pedoman Penelitian untuk skripsi, Tesis dan Disertai Ilmu Manajemen. Semarang: Universitas Diponegoro.

Bhuono, Agung Nugroho. 2005. Strategi Jitu Memilih Metode Statistik Penelitian dengan SPSS. Yogyakarta: Andi.

Drumond, Helga. 2003. Pengertian Keputusan Pembelian. Diambil dari: http://skripsimanajemen.blogspot.co $\mathrm{m} / 2012 / 12 /$ pengertiankeputusanpem belian.html (25Maret 2015)

Feigenbaum, A.V. 2000. Kendali Mutu Terpadu, Jilid 1, Edisi Ketiga. Jakarta : Erlangga.

Gaspersz, V. 2004. Production Planning and Inventory Control. Jakarta: PT. Gramedia Pustaka Utama.

Ghozali, Imam. 2001. Aplikasi Analisis Multivariate Dengan Program SPSS. Semarang : Badan Penerbit Universitas Diponegoro.

Ghozali, Imam. 2006. Aplikasi Analisis Multivariate Dengan Program SPSS, Cetakan Keempat. Semarang : Badan Penerbit Universitas Diponegoro.
Ghozali, Imam. 2007. Aplikasi Analisis Multivariate Dengan Program SPSS, Edisi Kedua. Semarang: Badan Penerbit Unversitas Diponegoro.

Ghozali, Imam. 2011. Aplikasi Analisis Multivariate Dengan Program SPSS. Semarang: Badan Penerbit Universitas Diponegoro.

Ghozali, I., dan Casstellan. 2002. Statistik Non Parametik iTori dan Aplikasi dengan Program SPSS. Semarang: Badan Pernerbit Universitas Diponegoro.

Iswayanti, Ika Putri. 2010. Analisis Pengaruh Kualitas Produk, Kualitas Layanan, Harga dan Tempat terhadap Keputusan Pembelian (Studi pada Rumah Makan "Soto Angkring Mas Boed" di Semarang). Jurnal Universitas Diponegoro.

Kotler, Philip. 2000. Manajemen Pemasaran, Edisi Milenium. Jakarta : Prehallindo.

Kotler, Philip. 2002. Manajemen Pemasaran, Analisa Perencanaan, Implementasi dan Control, Edisi Kesembilan, Jilid 1 dan Jilid 2. Alih Bahasa Hendra Teguh, dan Ronny A Rusli. Jakarta: Prehalindo.

Kotler, P., dan Gary Armstrong. 2001. PrinsipPrinsip Pemasaran, Jilid 1, Edisi Keduabelas. Jakarta : Erlangga.

Kotler, P., dan Gary Armstrong. 2003. DasarDasar Pemasaran, Jilid 1, Edisi Kesembilan. Alih Bahasa T. Hermaya. Jakarta: PT. Indeks Gramedia.

Kotler, P., dan Gary Armstrong. 2004. PrinsipPrinsip Marketing, Edisi Ketujuh. Jakarta: Salemba Empat.

Kotler, P., dan Gary Armstrong. 2008. PrinsipPrinsip Pemasaran, Jilid 1. Jakarta: Erlangga.

Kotler, P., dan Kevin Lane Keller. 2008. Manajemen Pemasaran, Jilid 1. Jakarta : Erlangga.

Kotler, P., dan Kevin Lane Keller. 2009. Manajemen Pemasaran, Jilid 1, Edisi Keduabelas. Alih Bahasa Benjamnin Molan. Jakarta : PT. Indeks. 
McCharthy, dan Perreault. 2003. DasarDasar Pemasaran. Alih Bahasa Agus Dharma. Jakarta: Erlangga.

Nugroho. 2003. Keputusan Pembelian. Diambil dari:

http://www.kajianpustaka.com/2014/ 03/keputusanpembelian.html $(25$ Maret 2016)

Pratiwi, Erika Putri. 2010. Analisis Pengaruh Kualitas Produk, Merek, dan Harga terhadap Keputusan Pembelian Konsumen Sepeda Motor Yamaha JupiterZ (Pada Dealer Yamaha Flag Ship Shop Pemuda Semarang). Jurnal Universitas Diponegoro.

Priyatno, Dwi. 2009. SPSS Untuk Analisis Korelasi, Regresi, dan Multivariate. Yogyakarta: Gava Media.

Priyatno. 2011. Buku Saku Analisis Statistik Data SPSS. Yogyakarta: MediaKom.

Purwanto, Asih. 2008. Pengaruh Kualitas Produk, Promosi, dan Desain terhadap Keputusan Pembelian Sepeda Motor Yamaha Mio pada Masyarakat di Wilayah Surakarta. Jurnal Universitas Muhammadiyah Surakarta.

Riduwan. 2009. Belajar Mudah Penelitian Untuk Guru, Karyawan, dan Peneliti Pemula. Diambil dari;

http://aresearch.upi.edu/operator/upl oad/s_geo_0700307_chapter3.pdf

Saladin, Djaslim. 2002. Manajemen Pemasaran. Bandung : PT. Linda Karya.

Saladin, Djaslim. 2003. Manajemen Pemasaran.

Diambil dari:

www.pengertianahli.com/2014.04/pe ngertianpromosimenurutparaahli.htm 1

(25 Maret 2016)

Saladin, Djaslim. 2004. Manajemen Pemasaran Analisis, Perencanaan, Pelaksanaan dan Pengendalian, Edisi Ketiga. Bandung : CV. Linda Karya.

Schiffman, Leon G., dan Kanuk. 2008. Consumer Behavior, Prentice Hall Internasional.

Sistaningrum. 2002. Manajemen Penjualan Produk. Yogyakarta: PT. Taristo.

Sugiyono. 2001. Metode Penelitian Administrasi. Bandung: Alfabeta.

Sugiyono. 2004. Metode Penelitian Bisnis. Bandung: Alfabeta

Sugiyono. 2008. Metode Penelitian Kuantitatif Kualitatif \& RND. Bandung : Alfabeta.

Sugiyono. 2010. Metode Penelitian Kuantitatif Kualitatif \& RND. Bandung : Alfabeta.

Sugiyono. 2011. Metode Penelitian Pendidikan. Bandung: Alfabeta.

Sugiyono. 2012. Memahami Penelitian Kualitatif. Bandung: Alfabeta.

Sugiyono. 2013. Metode Penelitian Pendidikan (Pendekatan Kuantitatif, Kualitatif, dan R\&D. Bandung : Alfabeta.

Swastha, Basu, dan T Hani Handoko. 2000. Manajemen Pemasaran, Analisa Perilaku Konsumen. Yogyakarta : BPFE - Yogyakarta.

Swastha, Basu, dan Irawan. 2002. Manajemen Pemasaran Modern, Edisi Kedua Cetakan Kesebelas. Yogyakarta: Liberty Offset.

Tjiptono, Fandi. 2008. Pemasaran Jasa. Malang: Bayu Media Publishing.

Tjiptono, Fandi. 2007. Strategi Pemasaran, Edisi kedua. Yogyakarta : Andi.

Umar. 2002. Riset Pemasaran dan Perilaku Konsumen, Cetakan kedua. Jakarta : Gramedia. 